\title{
INTEGRASI PENDIDIKAN KARAKTER RASA INGIN TAHU PADA PENGEMBANGAN BAHAN AJAR MATEMATIKA SD
}

\author{
Firmansyah $^{1}$, Purwati $^{2}$, Nahrun Najib Siregar ${ }^{3}$, Irfan Irnandi $^{4}$ \\ Universitas Papua, Indonesia \\ f.firmansyah@unipa.ac.id
}

\begin{abstract}
Integrating character education in teaching materials is one of the efforts made by the government to prevent the ethical and moral values degradation among adolescents, especially elementary students. Mathematical teaching materrials currentlyintegrate several characters in the material so that they are unfocused and less effective. The purpose of this research was to develop elementary mathematics teaching materials that integrated curiosity characters that were valid, practical and effective. Teaching materials that have been made are limited to class $I V$ $S D N$ Petompon 01 Semarang City. This research is a Reseach and Development $(R \& D)$. The procedure used is to simplify the Borg \& Gall development model. The Borg \& Gall development model consists of 10 steps but this study is limited to the seventh step due to the limitations of the researchers namely: 1) Potential and Problems; 2) data collection; 3) Product design; 4) Product Validation; 5) Design Revision; 6) Usability Test; 7) Product Revision. Data collection techniques are observation, interviews, drawing validator teaching materials and tests of learning outcomes. Data analysis techniques consist of validity, practicality and effectiveness data analysis. The results showed that (1) Mathematical teaching materials integrated valid curiosity characters with a score of 3.48 were in the excellent category. (2) Mathematics teaching material integrated with practical curiosity character with an observation score of 92.8 teacher activities and observation of student activities are in the very good category. (3) The mathematics teaching materials that integrated curiosity characters have been effective with criteria Student learning achievement in class who get integrated mathematics teaching materials character curiosity $75 \%$ classical completeness, and Student learning achievement using mathematics teaching materials that integrated curiosity characters better than student achievement with conventional learning.
\end{abstract}

Keywords: Teaching Material, Character, Curiosity

\begin{abstract}
Abstrak
Pengintegrasian Pendidikan karakter pada bahan ajar merupakan salah satu upaya yang dilakukan pemerintah untuk mencegah terjadinya degradasi nilai-nilai etika dan moral di kalangan remaja khususnya siswa SD. Bahan ajar matematika saat ini mengintegrasikan beberapa karakter dalam materi sehingga tidak fokus dan kurang efektif. Tujuan penelitian ini adalah untuk mengembangkan bahan ajar matematika SD yang terintegrasi karakter rasa ingin tahu yang valid, praktis dan efektif. Penelitian ini merupakan penelitian pengembangan atau Reseach and Development (R \& D). Prosedur yang digunakan adalah dengan menyederhanakan model pengembangan Borg \& Gall. Model pengembangan Borg \& Gall terdiri dari 10 langkah namun pada penelitian ini dibatasi sampai langkah ketujuh karena keterbatasan peneliti yaitu: 1) Potensi dan Masalah; 2) Pengumpulan data; 3) Desain produk; 4) Validasi Produk; 5) Revisi Desain; 6) Uji Coba keterpakaian; 7) Revisi Produk.Teknik pengumpulan data adalalah observasi, wawancara, lambar validator bahan ajar dan tes hasil belajar. Bahan ajar yang telah dibuat diujicoba terbatas pada kelas IV SD Petompon 01 Kota Semarang.Teknik analisis data terdiri dari analisis data kevalidan, kepraktisan dan keefektifan. Hasil penelitian menunjukkan bahwa: 1) Bahan ajar matematika terintegrasi karakter rasa ingin tahu valid dengan skor 3,48 berada pada kategori sangat baik. 2) Bahan ajar matematika terintegrasi karakter rasa ingin tahu praktis dengan skor pengamatan kegiatan guru 92,8 dan pengamatan kegiatan siswa berada pada kategori sangat baik. 3) Bahan ajar matematika terintegrasi karakter rasa ingin tahu telah efektif dengan kriteria prestasi belajar siswa pada kelas yang mendapatkan bahan ajar matematika terintegrasi karakter rasa ingin tahu mencapai ketuntasan klasikal 75\%, dan Prestasi belajar siswa yang menggunakan bahan ajar matematika terintegrasi karakter rasa ingin tahu lebih baik daripada prestasi belajar siswa dengan pembelajaran konvensional.
\end{abstract}

Kata Kunci: Bahan Ajar, Karakter, Rasa Ingin Tahu

\begin{tabular}{llll}
\hline Received & $: 2020-06-07$ & Approved & $: 2020-06-30$ \\
Reviesed & $: 2020-06-11$ & Published & $: 2020-07-31$ \\
\hline
\end{tabular}


Jurnal Cakrawala Pendas is licensed under a Creative Commons AttributionShareAlike 4.0 International License.

\section{Pendahuluan}

Kemampuan anak Indonesia usia 15 tahun dalam matematika, sains dan membaca masih berada pada peringkat ke-63 dari 69 negara yang berpartisipasi dalam PISA pada tahun 2015. Peringkat tersebut tidak berbeda jauh dengan hasil tes dan survey PISA pada tahun 2012. Rata-rata skor matematika, membaca dan sains anak anak Indonesia adalah 386, 397, 403, jauh di bawah rata-rata skor anak di negara OECD, yaitu 490, 493, 493 (PISA, 2015). Hal tersebut selaras dengan Trends International Mathematics and Sience Study (TIMMS) yang mengungkapkan bahwa Indonesia ikut survei empat tahunan dalam menilai kemampuan Matematika dan Sains siswa kelas IV SD. Selama ini yang diikutkan siswa kelas VIII. Lagi-lagi Indonesia di urutan bawah. Skor Matematika 397, menempatkan Indonesia di nomor 45 dari 50 negara. Berdasarkan hasil tersebut, kita dapat menyimpulkan bahwa kemampuan matematika siswa SD tergolong rendah. Hal tersebut menjadi bahan evaluasi dalam peningkatan kualitas pendidikan khususnya mata pelajaran matematika.

Pembangunan kualitas pendidikan tidak dapat dilepaskan dari pembangunan karakter. Pembangunan karakter yang merupakan upaya perwujudan amanat Pancasila dan Pembukaan UUD 1945 dilatar belakangi oleh realita permasalahan kebangsaan yang berkembang saat ini, seperti: disorientasi dan belum dihayatinya nilai-nilai Pancasila; keterbatasan perangkat kebijakan terpadu dalam mewujudkan nilai-nilai Pancasila; bergesernya nilai etika dalam kehidupan berbangsa dan bernegara; memudarnya kesadaran terhadap nilai-nilai budaya bangsa; ancaman disintegrasi bangsa; dan melemahnya kemandirian bangsa. Pupusnya karakter bangsa juga ditunjukkan oleh anak-anak usia sekolah, seperti yang beritakan dalam Kompas (2014) : Kenakalan remaja di Indonesia semakin meresahkan. Di Jakarta saja, kondisinya mungkin sudah darurat. Sepanjang tahun ini saja, tercatat 769 kasus tawuran pelajar. Dengan demikian, bila dibuat rata-ratanya, setiap hari terjadi dua tawuran. Dan ini sudah menelan 13 nyawa. Dunia remaja telah merupakan hal yang mencemaskan. Kenakalan lain adalah menyangkut masalah Narkoba. Data menunjukkan, dari 4 jutaan pecandu Narkoba, sebanyak 70 persen atau $3 / 4$ di antaranya adalah anak usia sekolah yaitu yang berusia 14 sampai dengan 20 tahun.

Salah satu upaya yang dilakukan pemerintah untuk mencegah terjadinya degradasi nilai-nilai etika dan moral di kalangan remaja adalah mengintegrasikan pendidikan karakter dengan mata pelajaran. Dewi (2015:118) menuturkan bahwa untuk mencegah semakin parahnya krisis akhlak pada generasi muda, pendidikan karakter dapat diintegrasikan ke dalam setiap mata pelajaran, termasuk mata pelajaran matematika dari tatanan nilai-nilai moral yang berlaku di masyarakat, yang akhirnya membawa remaja tersebut tersesat hidupnya. Salah satu bentuk integrasi yang dapat dilakukan adalah integrasi karakter pada bahan ajar khususnya pembelajaran matematika.

Hasil studi pendahuluan yang dilakukan di SDN Petompon 01 dan SDN Petompon 03 Kota Semarang diperoleh informasi bahwa pada penerapan kurikulum 2013, bahan ajar yang disediakan oleh pemerintah menekankan beberapa karakter dalam satu materi ajar sehingga tidak fokus, dan mendalam sehingga kurang efektif. Berdasarkan hasil wawancara dengan guru kelas IV dan V diperoleh fakta bahwa pendidikan karakter pada pembelajaran matematika pada kurikulum 2013 revisi 2016 bersifat tidak wajib pada pembelajaran matematika dikarenakan pendidikan karakter. Hal tersebut didukung oleh ditiadakannya Kompetensi Inti 3 (afektif) pada permendikbud No. 24 tahun 2016 Lampiran 14 tentang kompetensi inti dan kompetensi dasar matematika SD/MI. Kompetensi Inti 3 pada mata pelajaran di SD difokuskan pada mata 
pelajaran pendidikan agama dan pendidikan kewarganegaraan. Dampak kebijakan tersebut yaitu nilai-nilai karakter sudah tidak dicantumkan dalam perangkat pembelajaran lainnya namun secara tersirat masih ditanamkan pada pembelajaran matematika.

Integrasi pendidikan karakter pada kurikulum dewasa ini yaitu memasukkan lebih dari 2 nilai karakter pada satu kompetensi dasar atau materi pokok sehingga tidak terfokus sehingga bersifat sebagai tempelan sehingga tidak efektif dalam pembentukan karakter di SD. Hasil penelitian Suharto (2013), Mulyana (2013), Pujiastuti (2012) menunjukkan bahwa integrasi karakter dengan fokus memetakan satu karakter dengan satu materi pokok atau kompetensi dasar dapat menghasilkan peningkatan karakter bagi siswa. Selain fokus, integrasi pendidikan karakter pada kurikulum matematika perlu bersifat berjenjang dan spiral sehingga terjadi pembiasaan bagi siswa terhadap proses internalisasi indikator nilai karakter.

Berdasarkan uraian di atas, peneliti menarik kesimpulan bahwa penelitian yang bertujuan untuk mengembangkan bahan ajar mata pelajaran matematika SD terintegrasi karakter ini sangat dibutuhkan. Hal ini diupayakan sebagai solusi dari degradasi karakter siswa di Indonesia yang mulai tampak. Hasil nyata penelitian ini adalah tersusunnya bahan ajar matematika yang terintegrasi pendidikan karakter rasa ingin tahu yang valid, praktis dan efektif sehingga dapat digunakan sebagai suplemen dan referensi dalam penyelenggaraan proses belajar mengajar matematika pada jenjang SD.

\section{Metode Penelitian}

Penelitian ini merupakan penelitian pengembangan atau Reseach and Development ( $\mathrm{R} \&$ D). Penelitian pengembangan atau Reseach and Development ( $\mathrm{R} \& \mathrm{D})$ merupakan metode penelitian yang digunakan untuk menghasilkan produk tertentu dan menguji keefektifan produk tersebut (Sugiyono, 2012: 297). Prosedur pengembangan perangkat pembelajaran yang digunakan adalah dengan menyederhanakan model pengembangan Borg \& Gall. Model pengembangan Borg \& Gall (dalam Sugiyono: 298-331) terdiri dari 10 langkah yaitu: 1) Potensi masalah; 2) Pengumpulan data; 3) Desain produk; 4) Validasi produk; 5) Revisi desain; 6) Uji coba keterpakaian; 7) Revisi produk; 8) Uji coba produk; 9) Revisi produk; 10) Pembuatan produk massal. Penelitian ini dibatasi sampai langkah ketujuh karena keterbatasan peneliti.

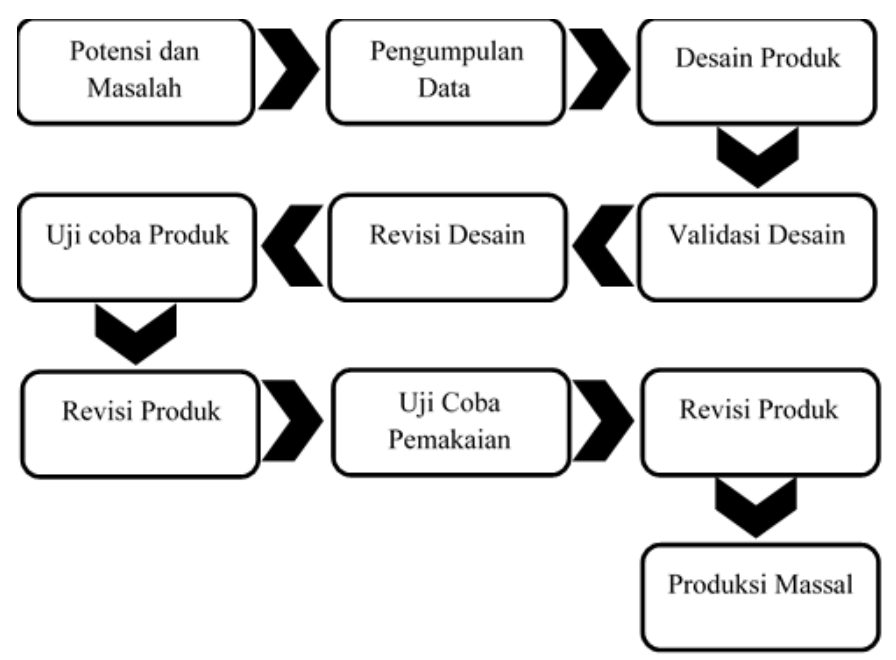

Gambar 1 Langkah-langkah Penggunaan metode RnD Borg and Gall (Sugiono, 2012: 298) 
Berikut ini penjelasan tujuh tahapan pengembangan bahan ajar matematika SD terintegrasi karakter rasa ingin tahu. Penelitan dapat berangkat dari adanya potensi atau masalah. Kegiatan pada tahap ini adalah melakukan penelitian pendahuluan berupa pengumpulan informasi tentang potensi dan permasalahan yang ada dilapangan. Pengumpulan data merupakan tindak lanjut setelah menganalisis potensi dan masalah yang ada di lapangan melalui survei lapangan.

Tahap Desain produk adalah membuat produk berupa bahan ajar matematika SD terintegrasi karakter rasa ingin tahu. Produk yang dikembangkan berupa bahan ajar matematika SD kelas IV materi pengukuran sudut. Setelah draft bahan ajar tersusun dilanjutkan ketahap Focus Group Discussion (FGD) sehingga mendapatkan saran dan perbaikan terhadap produk yang telah dikembangkan. Setelah itu dilanjutkan ketahap validasi produk oleh lima orang ahli yang terdiri dari ahli pengembangan perangkat pembelajaran, ahli evaluasi pembelajaran, ahli matematika SD serta 2 orang praktisi. Instrumen yang digunakan berupa lembar validasi. Revisi produk merupakan kegiatan merevisi kekurangan dan menyempurnakan produk berdasarkan hasil evaluasi para ahli/ Validator. Revisi desain mungkin dilakukan lebih dari satu kali, hal ini dilakukan hingga desain bahan ajar matematika SD terintegrasi karakter rasa ingin tahu valid.

Pada Uji coba keterpakaian, draft bahan ajar diujicoba secara terbatas pada siswa kelas IV SD. Hasil uji coba keterpakaian ini akan akan diperoleh masukan dan saran dari lapangan yang selanjutnya dianalisis untuk dilakukan revisi produk sehingga diperoleh bahan ajar matematika SD terintegrasi karakter rasa ingin tahu yang praktis dan efektif. Kegiatan revisi produk yaitu mengevaluasi hasil uji keterpakaian produk, mengkaji kekurangan, dan menyempurnakan kekurangan. Data yang diperoleh dari hasil uji coba dianalisis dan dilakukan revisi. Uji coba keterpakaian dan revisi produk ini dapat dilakukan secara berulang sampai diperoleh draf bahan ajar praktis dan efektif.

Penelitian pengembangan ini dilaksanakan pada siswa kelas IV SDN Petompon 1 kota Semarang tahun ajaran 2016/2017. Pada pengambilan sampel peneliti menggunakan tehnik cluster random sampling sehingga terpilih kelas IV A sebagai kelas kontrol dan IV B sebagai kelas eksperimen. Instrumen pengumpulan data pada penelitian ini yaitu 1) lembar FGD, 2) Lembar penilaian validator, 3) Tes hasil belajar, 4) Lembar pegamatan psikomotor dan 5) Lembar pengamatan karakter rasa ingin tahu, 6) Lembar pengamatan kegiatan guru, 7) Lembar pengamatan kegiatan siswa.

Tehnik analisis data terdiri dari: 1) analisis data kevalidan menggunakan pengujian internal yaitu pendapat ahli (expert review) terhadap perangkat. 2) analisis data kepraktisan menggunakan data hasil pengamatan kegiatan guru dan siswa dan, 3) analisis data keefektifan uji ketuntasan prestasi belajar menggunakan Uji Z dan uji perbedaan rata-rata prestasi belajar menggunakan Independent sample t-test, 4) analis peningkatan karakter rasa ingin tahu mengunakan Uji Gain.

\section{Hasil dan Pembahasan}

1. Desain Bahan Ajar

Bahan ajar yang dikembangkan berisi materi pengukuran sudut untuk kelas IV SD. Tahap selanjutnya peneliti mengkaji karakter yang sesuai dengan materi pengukuran sudut. Proses pemilihan karakter adalah dengan mengkaji mengkaji indikator dari 18 nilai pendidikan karakter. 18 Nilai-nilai karakter yang dikaji untuk diintegrasikan yaitu : (1) religius, (2) jujur, (3) toleransi, (4) disiplin, (5) kerja keras, (6) kreatif, (7) mandiri, (8) demokratis, (9) rasa ingin tahu, (10) semangat kebangsaan, (11) cinta tanah air, (12) menghargai prestasi, (13) bersahabat/ 
komunikatif, (14) cinta damai, (15) gemar membaca, (16) peduli lingkungan, (17) peduli sosial dan (18) tanggung jawab. Setelah pengkajian indikator, peneliti memilih karakter rasa ingin tahu untuk diintegrasikan kedalam bahan ajar. Pemilihan satu karakter dianggap sangat efektif agar lebih fokus ditanamkan dalam diri siswa.

Bahan ajar disusun berdasarkan 8 kriteria yaitu 1) Format, 2) tujuan pembelajaran, 3) Karakter rasa ingin tahu, 4) peta konsep, 5) Materi Pokok, 6) Soal latihan, 7) Daftar Pustaka, 8) Bahasa. Setelah bahan ajar tersusun kemudian melalui proses desain sampul da nisi sehingga menarik untuk dibaca oleh siswa.

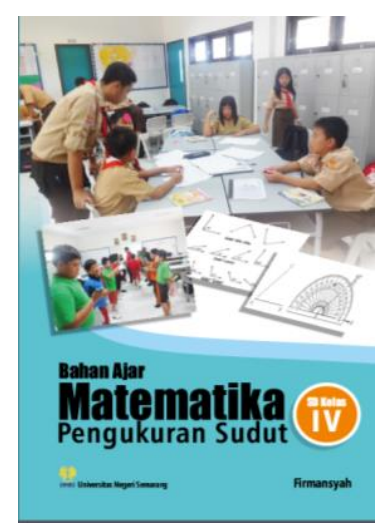

Gambar 2 Cover bahan ajar

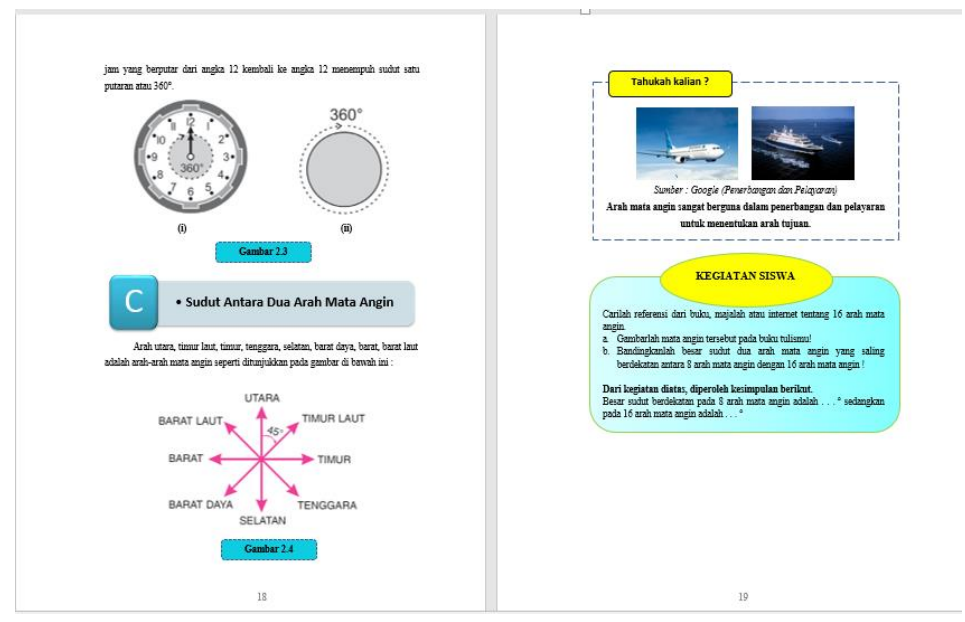

Gambar 3 Materi pada bahan ajar berisi muatan karakter rasa ingin tahu

Bahan ajar yang telah melalui proses desain kemudian melalui tahap Focus Group Discussion dengan KKG Gugus Sudirman Kota Semarang. FGD dilakukan untuk menyempurnakan prototype 1 yang telah disusun. Tahap FGD diikuti oleh guru-guru dan kepala sekolah Gugus Sudirman yang terdiri dari 7 Sekolah Dasar yaitu : SDN Petompon 01, SDN Petompon 02, SDN Petompon 03, SDN Gajah mungkur 01, SDN Gajah mungkur 03, SD A1Huda dan SD Maranatha 02.

Focus Group Discussion dengan KKG Gugus Sudirman Kota Semarang dilaksanakan pada hari Sabtu, 18 Februari 2017 di Aula SDN Petompon 02. FGD dihadiri oleh 53 peserta yang terdiri dari 11 guru kelas 1, 9 guru kelas 2, 10 guru kelas 3, 10 guru kelas IV, 10 guru kelas V, dan 3 kepala sekolah. Proses FGD terbagi menjadi 2 sesi yaitu diskusi panel dan diskusi 
kelompok. Setelah melalui proses FGD, bahan ajar kemudian direvisi berdasarkan saran dari peserta FGD.

2. Kevalidan Bahan Ajar

Tahap validasi produk bahan ajar matematika SD Terintegrasi karakter rasa ingin tahu divalidasi oleh 5 orang ahli/ pakar. Tujuan validasi produk adalah menghasilkan produk bahan bahan ajar matematika SD Terintegrasi karakter rasa ingin tahu yang valid. Penilaian yang diberikan validator menggunakan skala 1 sampai 4 . Hasil penilaian dianalisis berdasarkan ratarata hasil skor yang diberikan oleh validator. Aspek kevalidan bahan ajar meliputi 1) Format, 2) tujuan pembelajaran, 3) Karakter rasa ingin tahu, 4) peta konsep, 5) Materi Pokok, 6) Soal latihan, 7) Daftar Pustaka, 8) Bahasa

Hasil penilaian kelima validator terhadap draf bahan ajar yang telah disusun dapat dilihat pada tabel berikut:

Tabel 1 Hasil validasi produk

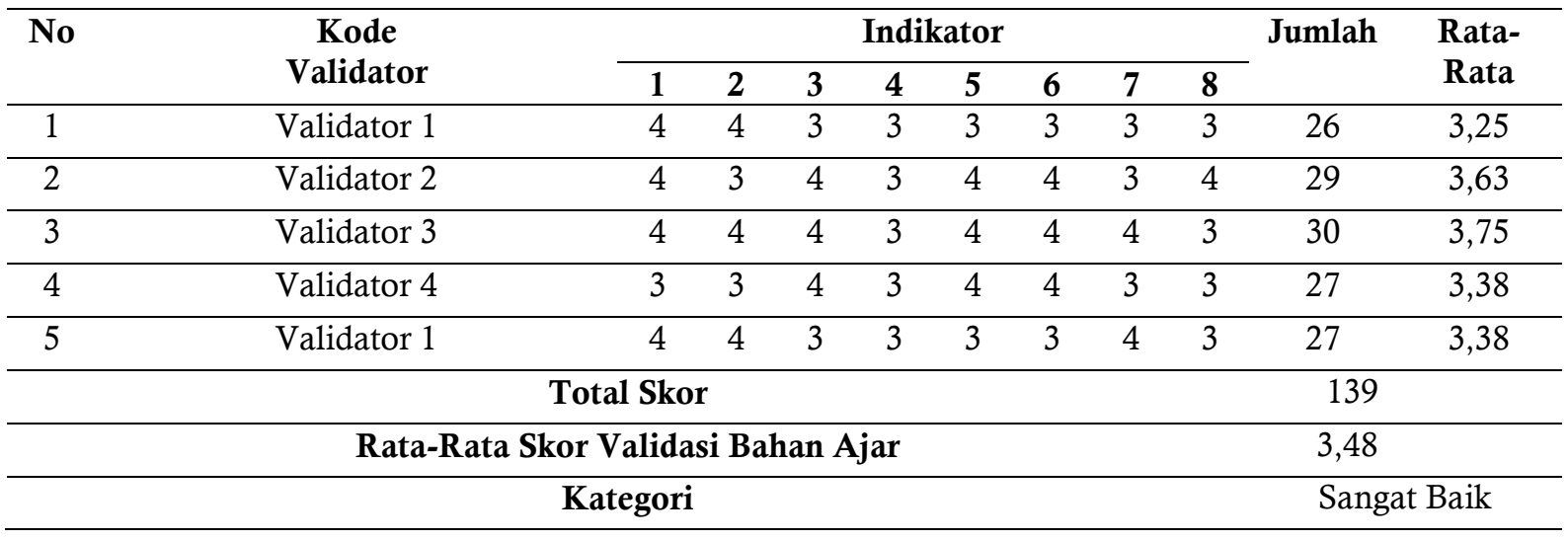

Berdasarkan Tabel 1 diperoleh rata-rata 3,48 dengan kriteria sangat baik, yaitu valid dan dapat digunakan untuk penelitian. Masukan berupa saran dari validator untuk Bahan ajar ini dapat dilihat pada Tabel 2 berikut ini.

Tabel 2 Hasil revisi Bahan Ajar

\begin{tabular}{cll}
\hline No & \multicolumn{1}{c}{ Saran validator } & \multicolumn{1}{c}{ Hasil revisi } \\
\hline 1 & $\begin{array}{l}\text { Perbaiki peta konsep (tambahkan } \\
\text { label/ kata penghubung antar } \\
\text { konsep) }\end{array}$ & $\begin{array}{l}\text { Pada peta konsep setiap pertemuan telah } \\
\text { ditambahkan kata penghubung antar } \\
\text { konsep. }\end{array}$ \\
\hline 2 & Berikan rangkuman & Menambahkan rangkuman \\
\hline 3 & $\begin{array}{l}\text { Muatan karakter perlu disampaikan } \\
\text { secara eksplisit }\end{array}$ & $\begin{array}{l}\text { Muatan karakter rasa ingin tahu telah } \\
\text { disampaikan secara eksplisit }\end{array}$ \\
\hline 4 & $\begin{array}{l}\text { Keterkaitan sudut segi banyak } \\
\text { dengan bentuk bangun segi } \\
\text { banyak.(besar sudutnya dan segi } \\
\text { banyak) belum dibahas. Hanya } \\
\text { ditulis cara mengukur sudut saja }\end{array}$ & $\begin{array}{l}\text { Menambahkan pembahasan keterkaitan } \\
\text { sudut segi banyak beraturan dengan } \\
\text { bentuk bangun segi banyak beraturan }\end{array}$ \\
\hline 5 & $\begin{array}{l}\text { Referensi dari buku yang telah } \\
\text { dicetak/ diterbitkan akan } \\
\text { memperkaya pemahaman dan } \\
\text { tingkat kemampuan belajar siswa, } \\
\text { maka akan lebih baik bila } \\
\text { diperbanyak }\end{array}$ & $\begin{array}{l}\text { Menambahkan sumber/ referensi dari } \\
\text { buku yang telah dicetak atau diterbitkan. }\end{array}$ \\
\hline
\end{tabular}

Saran dari validator terhadap bahan ajar ada enam yaitu pada bagian peta konsep, contoh soal dan rangkuman, integrasi karakter rasa ingin tahu, muatan materi dan referensi. 
Bahan ajar yang telah divalidasi tersebut kemudian direvisi berdasarkan saran masing-masing validator.

3. Kepraktisan Bahan Ajar

Uji coba keterpakaian dilakukan untuk mengetahui kepraktisan dan keefektifan produk. Kepraktisan bahan ajar diketahui dengan mengnalisis hasil pengamatan kegiatan guru dan siswa. Hasil analisis pengamatan kegiatan guru pada kelas eksperimen di Kelas IV B SD Petompon 01 Semarang selama 5 kali pertemuan yang berlangsung pada 15-29 maret 2017. Hasil pengamatan sebagai berikut:

Tabel 3 Rekapitulasi Hasil Pengamatan Guru

\begin{tabular}{|c|c|c|c|c|c|c|c|}
\hline \multirow[t]{2}{*}{ No } & \multirow{2}{*}{$\begin{array}{c}\text { Kelas } \\
\text { Eksperimen }\end{array}$} & \multicolumn{5}{|c|}{ Pertemuan } & \multirow{2}{*}{$\begin{array}{l}\text { Rata- } \\
\text { Rata }\end{array}$} \\
\hline & & 1 & 2 & 3 & 4 & 5 & \\
\hline 1 & Observer 1 & 83,3 & 83,3 & 94,4 & 100 & 100 & 92,2 \\
\hline 2 & Observer 2 & 83,3 & 94,4 & 94,4 & 94,4 & 100 & 93,3 \\
\hline \multicolumn{7}{|c|}{ Rata -Rata Keterlaksanaan Pembelajaran } & 92,8 \\
\hline
\end{tabular}

Sedangkan Hasil analisis pengamatan kegiatan siswa pada kelas eksperimen di Kelas IV B SD sebagai berikut:

Tabel 4 Rekapitulasi Hasil Pengamatan Siswa

\begin{tabular}{cccccccc}
\hline No & $\begin{array}{c}\text { Kelas } \\
\text { Eksperimen }\end{array}$ & $\mathbf{1}$ & $\mathbf{2}$ & $\mathbf{3}$ & $\mathbf{4}$ & $\mathbf{5}$ & Rata- \\
\cline { 3 - 6 } & & Rata \\
\hline 1 & Observer 1 & 77,8 & 83,3 & 94,4 & 100 & 100 & 88,9 \\
\hline 2 & Observer 2 & 83,3 & 94,4 & 94,4 & 94,4 & 100 & 91,6 \\
\hline \multicolumn{6}{c}{ Rata -Rata Keterlaksanaan Pembelajaran } \\
\end{tabular}

Berdasarkan hasil pengamatan kegiatan guru diperoleh rata - rata 92,2 berada pada katagori sangat baik dan hasil pengamatan kegiatan siswa diperoleh rata - rata 90,3 dan berada pada katagori sangat baik. Dari hasil tersebut dapat disimpulkan bahwa bahan ajar praktis digunakan dalam pembelajaran.

4. Keefektifan Bahan Ajar

Analisis keefektifan bahan ajar pada penelitian ini meliputi uji ketuntasan prestasi belajar dan uji perbedaan rata-rata prestasi belajar.

a. Uji Ketuntasan Prestasi Belajar

Kriteria pertama perangkat pembelajaran yang efektif pada penelitian ini adalah prestasi belajar siswa pada kelas yang menggunakan bahan ajar matematika yang terintegrasi dengan karakter rasa ingin tahu mencapai ketuntasan minimal 70 dan ketuntasan klasikal $75 \%$. Sebelum melakukan uji ketuntasan, peneliti melakukan uji asumsi prasyarat yang terdiri dari uji normalitas dan uji homogenitas. Data yang dianalisis pada bagian ini adalah nilai tes hasil belajar (posttest) siswa kelas Eksperimen (IV B).

Uji Asumsi Prasyarat

Sebelum dilakukan uji ketuntasan prestasi belajar, terlebih dahulu dilakukan uji normalitas pada nilai tes hasil belajar (posttest) siswa kelas Eksperimen (IV B). Hipotesis untuk uji normalitas dirumuskan sebagai berikut:

$\mathrm{H}_{0}$ : Data nilai Posttest siswa kelas eksperimen berdistribusi normal 
$\mathrm{H}_{1}$ : Data nilai Posttest siswa kelas eksperimen tidak berdistribusi normal

Uji normalitas pada tahap ini dilakukan dengan menggunakan uji Kolmogorov-Smirnov dengan bantuan SPSS Statistics 23.0. Taraf kesalahan yang digunakan adalah $\alpha=0,05$. Kriteria pengujiannya $\mathrm{H}_{0}$ diterima apabila signifikansi $>0,05$ artinya populasi berdistribusi normal. Hasil uji normalitas posttest siswa kelas Eksperimen dapat dilihat pada tabel 4

Tabel 5 Hasil Uji Normalitas Posttest siswa kelas eksperimen

\begin{tabular}{lllll}
\hline & \multicolumn{4}{c}{ Kolmogorov-Smirnov ${ }^{\mathbf{a}}$} \\
\cline { 2 - 5 } & Statistic & Df & Sig. \\
\hline Posttest &, 124 & $270^{*}$ \\
\hline
\end{tabular}

Berdasarkan hasil yang diperoleh pada tabel 5, uji normalitas nilai posttest kelas eksperimen dengan menggunakan uji Kolmogorov - Smirnov diperoleh nilai signifikansi $=0,200$ dimana $0,200>0,05$ sehingga $\mathrm{H}_{0}$ diterima. Artinya data nilai Posttest siswa kelas eksperimen berdistribusi normal.

Uji asumsi prasyarat yang kedua adalah uji homogenitas. Uji homogenitas pada penelitian ini dilakukan dengan melihat nilai kurtosisnya. Hasil uji homogenitas posttest siswa kelas eksperimen dapat dilihat pada tabel 6

Tabel 6 Hasil Uji Homogenitas Posttest siswa kelas eksperimen

\begin{tabular}{|c|c|c|c|c|}
\hline \multirow{3}{*}{$\begin{array}{l}\text { Posttest_I } \\
\text { VB }\end{array}$} & & & Statistic & Std. Error \\
\hline & \multirow{3}{*}{$\begin{array}{l}\text { Mean } \\
95 \% \text { Confidence Interval } \\
\text { for Mean }\end{array}$} & & 79,048 & 2,2980 \\
\hline & & Lower Bound & 74,324 & \\
\hline & & Upper Bound & 83,772 & \\
\hline & $5 \%$ Trimmed Mean & & 79,930 & \\
\hline & Median & & 80,000 & \\
\hline & Variance & & 142,586 & \\
\hline & Std. Deviation & & 11,9409 & \\
\hline & Minimum & & 45,7 & \\
\hline & Maximum & & 94,3 & \\
\hline & Range & & 48,6 & \\
\hline & Interquartile Range & & & \\
\hline & Skewness & & $-1,047$ & 448 \\
\hline & Kurtosis & & 1,273 & ,872 \\
\hline
\end{tabular}

Berdasarkan tabel 6 dapat diperoleh nilai kurtosis adalah -1,047. Nilai tesebut menunjukkan nilai negatif dekat dengan nol sehingga dapat disimpulkan bahwa data posttest siswa kelas eksperimen cenderung homogen.

1) Uji Asumsi Prasyarat

Ketuntasan prestasi belajar siswa secara klasikal pada penelitian ini menggunakan uji proporsi. Pada penelitian ini Kriteria Ketuntasan Minimal (KKM) pada pembelajaran matematika adalah 70 dengan ketuntasan klasikal 75\%.

Hipotesis untuk uji ketuntasan klasikal sebagai berikut :

$H_{0} \quad: \pi \leq(74,5 \%$ ( Minimal Persentase siswa yang mencapai KKM 70 adalah $75 \%$ )

$H_{1}: \pi>74,5 \%$ ( Persentase siswa yang mencapai KKM 70 lebih dari atau sama dengan $75 \%)$

Rumus statistik menggunakan uji proporsi satu pihak :

$$
z=\frac{\frac{x}{n}-\pi_{0}}{\sqrt{\frac{\pi_{0-\left(1-\pi_{0}\right)}}{n}}}
$$




$$
\begin{gathered}
z=\frac{\frac{23}{27}-0,75}{\sqrt{\frac{0,75(1-0,75)}{27}}} \\
z=1,23
\end{gathered}
$$

Berdasarkan hasil perhitungan diperoleh $\mathrm{z}_{\text {hitung }}=1,23$ lebih besar dibandingkan $\mathrm{z}_{\text {tabel }}=$ 0,8907 atau 1,23>0,8907 maka $\mathrm{H}_{0}$ ditolak dan $\mathrm{H}_{1}$ diterima. Jadi dapat disimpulkan bahwa proporsi ketuntasan klasikal prestasi belajar siswa kelas eksperimen mencapai ketuntasan klasikal lebih dari atau sama dengan $75 \%$.

b. Uji Perbedaan Rata-Rata Prestasi belajar

Kriteria kedua perangkat pembelajaran yang efektif pada penelitian ini adalah prestasi belajar siswa pada kelas yang menggunakan bahan ajar matematika yang terintegrasi dengan karakter rasa ingin tahu lebih baik daripada prestasi belajar siswa dengan pembelajaran konvensional. Sebelum melakukan uji perbedaan rata-rata prestasi belajar peneliti melakukan uji asumsi prasyarat yang terdiri dari uji normalitas dan uji homogenitas. Data yang dianalisis pada bagian ini adalah nilai tes hasil belajar (posttest) siswa kelas kontrol (IV A) dan kelas Eksperimen (IV B).

Uji asumsi prasyarat yang pertama pada uji perbedaan rata-rata prestasi adalah uji normalitas. Rumusan hipotesis uji normalitas sebagai berikut:

$\mathrm{H}_{0} \quad$ : Data nilai Posttest siswa kelas kontrol dan kelas eksperimen berdistribusi normal $\mathrm{H}_{1} \quad$ : Data nilai Posttest siswa kelas kontrol dan kelas eksperimen tidak berdistribusi normal

Uji normalitas pada tahap ini dilakukan dengan menggunakan uji Kolmogorov-Smirnov dengan bantuan SPSS Statistics 23.0. Taraf kesalahan yang digunakan adalah $\alpha=0,05$. Kriteria pengujiannya $\mathrm{H}_{0}$ diterima apabila signifikansi $>0,05$ artinya populasi berdistribusi normal. Hasil uji normalitas posttest siswa kelas Kontrol dan Kelas Eksperimen dapat dilihat pada tabel 7

Tabel 7 Hasil Uji Normalitas Posttest siswa kelas Kontrol dan Kelas Eksperimen

\begin{tabular}{lcccc}
\hline & \multicolumn{4}{c}{ Kolmogorov-Smirnov $^{\text {a }}$} \\
\cline { 2 - 5 } & & Statistic & Df & Sig. \\
\hline Nilai_Posttest & 109 & & 54 &, 161 \\
\hline
\end{tabular}

Berdasarkan hasil yang diperoleh pada tabel 7, uji normalitas nilai posttest kelas kontrol dan kelas eksperimen dengan menggunakan uji Kolmogorov - Smirnov diperoleh nilai signifikansi $=0,161$ dimana $0,161>0,05$ sehingga $\mathrm{H}_{0}$ diterima. Artinya data nilai Postest siswa kelas kontrol dan kelas eksperimen berdistribusi normal.

Uji asumsi prasyarat yang kedua pada uji perbedaan rata-rata prestasi belajar adalah uji homogenitas. Rumusan hipotesis uji homogenitas sebagai berikut:

$\mathrm{H}_{0} \quad$ : Varians Kelas Kontrol dan Kelas Eksperimen Homogen

$\mathrm{H}_{1} \quad$ : Varians Kelas Kontrol dan Kelas Eksperimen tidak Homogen

Uji homogenitas pada tahap ini dilakukan dengan menggunakan uji Levene's Test for Equality of Variances dengan bantuan SPSS Statistics 23.0. Taraf kesalahan yang digunakan adalah $\alpha=0,05$. Kriteria pengujiannya $\mathrm{H}_{0}$ diterima apabila signifikansi $>0,05$ artinya populasi berdistribusi homogen atau kedua kelompok homogen. Hasil uji homogenitas posttest siswa kelas Kontrol dan Kelas Eksperimen dapat dilihat pada tabel 8 
Tabel 8 Hasil Uji Homogenitas Posttest siswa kelas Kontrol dan Kelas Eksperimen

\begin{tabular}{llll}
\hline & & \multicolumn{2}{c}{$\begin{array}{c}\text { Levene's Test for Equality of } \\
\text { Variances }\end{array}$} \\
\cline { 3 - 3 } & & & Sig. \\
\hline Nilai_Pretest & Equal variances assumed & F & \\
\cline { 3 - 4 } & Equal variances not assumed & \\
\hline
\end{tabular}

Berdasarkan hasil yang diperoleh pada tabel 8 , uji homogenitas nilai posttest kelas kontrol dan kelas eksperimen dengan menggunakan uji Levene's Test for Equality of Variances diperoleh nilai signifikansi $=0,520$ dimana $0,520>0,05$ sehingga $\mathrm{H}_{0}$ diterima. Artinya varians Kelas Kontrol dan Kelas Eksperimen Homogen.

Setelah asumsi prasyarat normalitas dan homogenitas terpenuhi, maka analisis dilanjutkan dengan uji perbedaan rata-rata prestasi belajar (Posttest). Analisis yang digunakan pada tahap ini adalah uji Independent sample t-test dengan bantuan SPSS Statistics 23.0. Hipotesis yang dirumuskan sebagai berikut:

$H_{0}: \mu 1 \leq \mu 2 \quad$ (Prestasi belajar posttest siswa pada kelas yang menggunakan bahan ajar matematika yang terintegrasi dengan karakter rasa ingin tahu tidak lebih baik atau sama dengan prestasi belajar posttest siswa dengan pembelajaran konvensional)

$H_{1}: \mu 1>\mu 2 \quad$ (Prestasi belajar posttest siswa pada kelas yang menggunakan bahan ajar matematika yang terintegrasi dengan karakter rasa ingin tahu lebih baik daripada prestasi belajar posttest siswa dengan pembelajaran konvensional)

Taraf kesalahan yang digunakan adalah $\alpha=0,05$. Kriteria pengujian adalah $\mathrm{H}_{0}$ diterima apabila signifikansi $>0,05$ artinya rata-rata Prestasi belajar Posttest kelas kontrol dan kelas eksperimen tidak lebih baik atau sama. Hasil uji Perbedaan Rata-Rata Prestasi belajar Posttest kelas kontrol dan kelas eksperimen dapat dilihat pada tabel 9

Tabel 9 Hasil Uji Rata-Rata Prestasi Belajar Posttest siswa kelas Kontrol dan Kelas Eksperimen

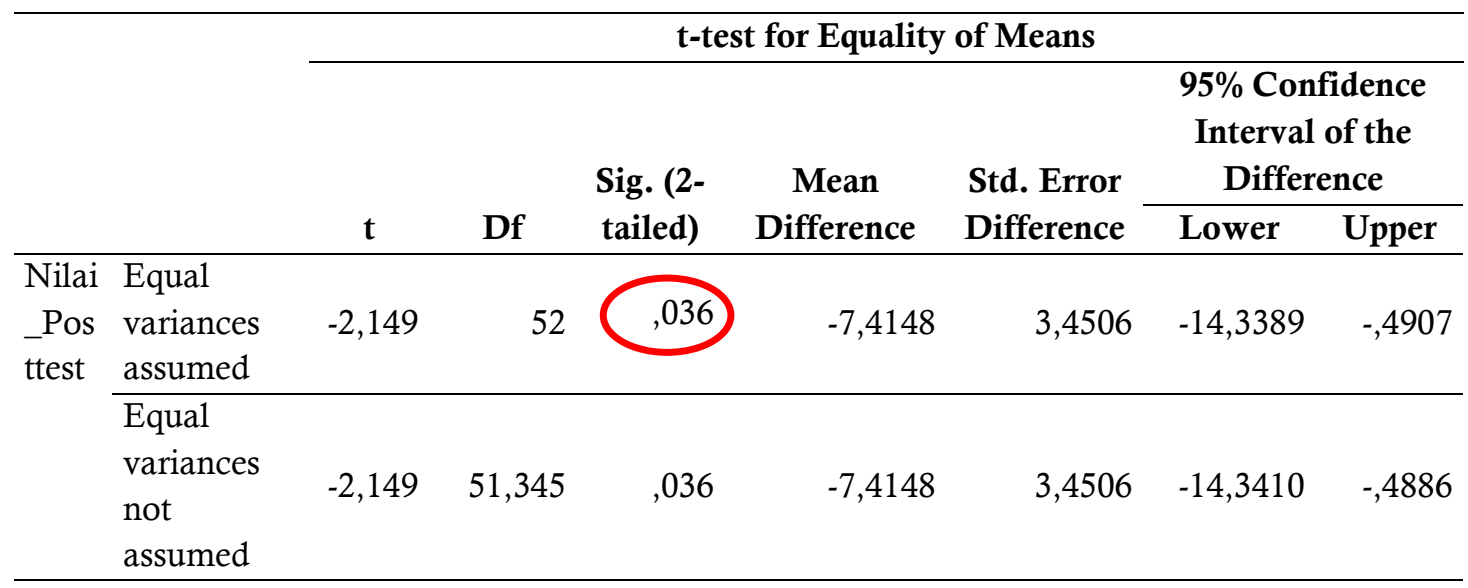

Berdasarkan hasil yang diperoleh pada Tabel 7, uji Perbedaan Rata-Rata THB Posttest kelas kontrol dan kelas eksperimen dengan menggunakan uji Independent sample t-test diperoleh nilai signifikansi $=0,036$ dimana $0,036<0,05$ sehingga $\mathrm{H}_{0}$ ditolak. Artinya prestasi belajar 
posttest siswa pada kelas yang menggunakan bahan ajar matematika yang terintegrasi dengan karakter rasa ingin tahu lebih baik daripada prestasi belajar posttest siswa dengan pembelajaran konvensional. Hal ini sesuai dengan hasil penelitian Suharto (2013), Mulyana (2013), Pujiastuti (2012) yang menjelaskan bahwa integrasi satu karakter untuk satu kompetensi dasar/ materi pokok akan efektif meningkatkan prestasi belajar serta fokus membangun karakter pada diri siswa.

5. Peningkatan karakter rasa ingin tahu

Peningkatan karakter rasa ingin tahu pada penelitian ini dianalisis secara klasikal dan individual. Uji peningkatan karakter rasa ingin tahu secara klasikal menggunakan rata-rata hasil pengamatan karakter rasa ingin tahu setiap pertemuan. Hasil analisis nilai gain karakter rasa ingin tahu secara klasikal dapat dilihat pada tabel 10 berikut.

Tabel 4.30 Hasil Analisis nilai Gain Karakter Rasa Ingin Tahu secara Klasikal

\begin{tabular}{ccccc}
\hline Pertemuan Ke & $\mathrm{S}_{\text {awal }}$ & $\mathrm{S}_{\text {akhir }}$ & Nilai Gain $(\mathrm{g})$ & Kategori \\
\hline 1 dan 2 & 63,6 & 67,5 & 0,11 & Rendah \\
\hline 2 dan 3 & 67,5 & 72,3 & 0,15 & Rendah \\
\hline 3 dan 4 & 72,3 & 77,5 & 0,19 & Rendah \\
\hline 4 dan 5 & 77,5 & 80,3 & 0,12 & Rendah \\
\hline 1 dan 5 & 63,6 & 80,3 & 0,46 & Sedang \\
\hline
\end{tabular}

Berdasarkan hasil perhitungan nilai gain pada tabel 10 dapat diketahui bahwa nilai gain karakter rasa ingin tahu pada pertemuan pertama ke pertemuan kedua, pertemuan kedua ke pertemuan ketiga, pertemuan ketiga ke pertemuan keempat, pertemuan keempat ke pertemuan kelima berada pada kategori rendah. Data tersebut menunjukkan peningkatan tidak tercapai setiap pertemuan. Seangkan pada pertemuan pertama ke pertemuan kelima terjadi peningkatan kategori sedang. Sehingga dapat disimpulkan bahwa karakter rasa ingin tahu siswa meningkat dari pertemuan pertama kepertemuan kelima.

Uji peningkatan karakter rasa ingin tahu secara individual menggunakan hasil pengamatan karakter rasa ingin tahu pada pertemuan pertama dan pertemuan kelima setiap siswa. Rekapitulasi nilai gain karakter rasa ingin tahu secara individual disajikan pada tabel 11.

Tabel 11 Rekapitulasi nilai Gain Karakter Rasa Ingin Tahu secara Individual

\begin{tabular}{ccc}
\hline Kategori & Jumlah Siswa & Presentase \\
\hline Tinggi & 3 & $11,1 \%$ \\
\hline Sedang & 21 & $77,8 \%$ \\
\hline Rendah & 3 & $11,1 \%$ \\
\hline
\end{tabular}

Berdasarkan Rekapitulasi nilai gain secara individual pada tabel 11 dapat diketahui peningkatan karakter rasa ingin tahu setiap siswa. Hasil analisis menunjukkan 3 siswa $(11,1 \%)$ memperoleh nilai gain kategori rendah, 21 siswa $(77,8 \%)$ memperoleh nilai gain kategori kategori sedang dan 3 siswa $(11,1 \%)$ memperoleh nilai gain kategori tinggi. Sehingga dapat disimpulkan bahwa 24 siswa $(88,9 \%)$ siswa mengalami peningkatan karakter rasa ingin tahu.

Peningkatan karakter terjadi karena karakter yang diintegrasikan pada bahan ajar difokuskan hanya satu sehingga siswa terbiasa melaksanakan kegiatan-kegiatan yang terdapat dalam bahan ajar. Hal ini sesuai dengan Sukestiyarno (2015) yang menyatakan bahwa membatasi dan memfokuskan jumlah karakter dalam pembelajaran akan menghasilkan peningkatan karakter dan hasil belajar matematika siswa.

\section{Kesimpulan}


Berdasarkan hasil penelitian dan pemahasan diatas dapat disimpulkan bahwa (1) Bahan ajar matematika terintegrasi karakter rasa ingin tahu valid dan berada pada kategori sangat baik. (2) Bahan ajar matematika terintegrasi karakter rasa ingin tahu praktis dengan skor keterlaksanaan RPP berada pada kategori sangat baik. (3) Prestasi belajar siswa pada kelas yang mendapatkan bahan ajar matematika terintegrasi karakter rasa ingin tahu mencapai ketuntasan klasikal, serta Prestasi belajar siswa yang menggunakan bahan ajar matematika terintegrasi karakter rasa ingin tahu lebih baik daripada prestasi belajar siswa dengan pembelajaran konvensional. Sehingga dapat disimpulkan bahwa Bahan ajar matematika terintegrasi karakter rasa ingin tahu telah valid, praktis dan efektif sehingga dapat digunakan pada proses pembelajaran.

Implementasi bahan ajar matematika SD terintegrasi karakter rasa ingin tahu ini terbukti mampu meningkatkan karakter rasa ingin tahu siswa secara klasikal dan individual. Namun demikian, pembiasaan terhadap karakter perlu diterapkan tidak hanya dalam pembelajaran namun diluar pembelajaran sehingga internalisasi karakter kedalam diri siswa dapat maksimal.

\section{Daftar Pustaka}

Abdurrahman, M. (2012). Anak Berkesulitan Belajar : Teori, Diagnosis, dan Rekomendasinya , Jakarta: Rineka Cipta.

Afandi, R. (2011). Integrasi Pendidikan Karakter Dalam Pembelajaran IPS di Sekolah Dasar. Jurnal Pedagogia. 1(1): 85-98

Arikunto, S. (2009). Dasar-Dasar Evaluasi Pendidikan. Jakarta: Bumi Aksara.

Arikunto, S. (2011). Prosedur Penelitian Suatu Pendekatan Praktik. Jakarta: Rineka Cipta

Benninga, JS \& Marvin WB \& Phyllis K \& Karen Smith. (2003). The relationship of Character EducationImplementation And Achievement in Elementary Schools. International Journal of Research Education. 1(1) pp.19-32

Bialik, M., Michael B., Charles F., Michaela. (2015). Character Education For the 21st Century: What Should Students Learn?. Boston: Center for Curriculum Redesign.

Buchori, A \& Setyawati, R. D. (2015). Development Learning Model of Character Education Through E-Comic in Elementary School. International Journal of Education and Research.3 (9) : 369-386

Daryanto \& Darmiatun, S. (2013). Implementasi Pendidikan Karakter di Sekolah. Yogyakarta: Gava Media.

Dewi, Y. (2015). Pendidikan Karakter dalam Pembelajaran Matematika. Jurnal Pendidikan Matematika, 1(2): 117-124

Heruman. (2008). Model Pembelajaran Matematika di Sekolah Dasar. Bandung: Rosda Karya Hidayati, Abna \& M. Zaim \& Kasman Rukun \& Darmansyah. (2014). The Development of Character Education curriculum For Elementary Student in West Sumatera. International Journal of Education and Research.2 (6)

Huda, Miftahul. (2013). Cooperative Learning : Metode, Teknik, Struktur, dan Model Penerapan, Yogyakarta: Pustaka Pelajar.

Kementrian Pendidikan dan Kebudayaan. (2016). Silabus Mata Pelajaran Matematika Sekolah Dasar/Madrasah Ibtidaiyah. Jakarta

Kementrian Pendidikan Nasional. (2011). Pengembangan Pendidikan Budaya dan Karakter Bangsa Melalui Pembelajaran Matematika di SD. Jakarta : Badan Pengembangan SDM dan Penjaminan Mutu Pendidikan

Kompas. (2014). Fokus : Darurat Kenakalan Remaja. http://hariansib.co/view/TajukRencana/39890/Darurat-Kenakalan-Remaja.html\#.VtB8d_197IU diunduh 26 Februari 2016.

Lickona, T. (2013). Education For Character :Mendidik untuk Membentuk Karakter. Terjemahan Juma Abdu Wamaungo. Jakarta: Bumi Aksara 
Menteri Pendidikan dan Kebudayaan. (2014). Pelaksanaan Kurikulum 2013. Kementrian Pendidikan dan Kebudayaan Republik Indonesia

Mulyana, S. (2013). Pengembangan Perangkat Pembelajaran Matematika Model Cooperative Learning Tipe STAD Bermuatan Pendidikan Karakter Pada Materi Pecahan Desimal Kelas V. Tesis. Semarang: Program Pascasarjana Unnes

NCTM. (2000). Executive Summary: Principles and standards for school mathematics. Reston, VA: National Council of Teachers of Mathematics.

Permendikbud tahun 2016 No. 22 tentang Standar Proses Pendidikan Dasar dan Menengah

Permendikbud No.24 Tahun 2016 tentang kompetensi inti dan kompetensi dasar

Permendiknas No. 22 Tahun 2006 tentang standar isi untuk satuan pendidikan dasar dan menengah

PISA. (2015). PISA Result in Focus. Organization for Economic Cooperation and development (https://www.oecd.org/pisa/pisa-2015-results-in-focus.pdf). Diunduh 1 Juli 2017

Pujiastuti. 2012. Pengembangan Perangkat Pembelajaran Matematika Model Cooperative Group Investigation Bermuatan Pensdidikan Karakter untuk Meningkatkan Kemampuan Pemecahan Masalah Matreri Himpunan Siswa Kelas VII. Tesis. Semarang: Program Pascsarjana Unnes

Reynolds, Cecil R., R.B. Livingston, \& Victor Willson. (2010). Measurement and Assesment in Education Second Edition. New Jersey: Pearson Prentice Hall.

Rusilowati, Ani., Hartono., Supriyadi. (2012). Pengembangan model pembelajaran Better Teaching and Learning Berkarakter untuk Membekali Kompetensi Pedagogi Mahasiswa Calon Guru. Jurnal Penelitian Pendidikan, 29 (2): 83-92

Samani, M. \& Hariyanto. (2014). Konsep dan Model Pendidikan Karakter. Bandung: PT Remaja Rosdakarya

Sudjana. (2005). Metoda Statistika. Bandung: Tarsito.

Sugiyono. (2012). Metode Penelitian Pendidikan (Pendekatan quantitatif, Kualitatif, dan R\&D). Bandung : Alfabeta.

Sugiyono. (2015). Metode Penelitian \& Pengembangan (Research and Development). Bandung: Alfabeta.

Suharto. (2013). Pembelajaran Matematika dengan Pendekatan Kontekstual Bermuatan Pendidikan Karakter Untuk Meningkatkan Kemampuan Komunikasi Matematis Materi Program Linier Kelas XI. Tesis. Semarang: Program Pascsarjana Unnes

Sukestiyarno. (2014). Statistika Dasar. Yogyakarta : Andi Offset

Sukestiyarno. (2015). Integrasi Nilai Pendidikan Karakter. Suara Merdeka 27 Februari 2015. Diakses tanggal 21 April 2017.

Tran, V. D. (2014). The effects of Cooperative Learning on the Academic Achievement and Knowledge Retention. International Journal of Higher Education.3 (2) : 131-140

Wibowo, T. (2010). Pentingnya Pendidikan Karakter Dalam Dunia Pendidikan. Diakses dari http://www.pendidikankarakter.com/pentingnya-pendidikan-karakter-dalam-duniapendidikan/ diunduh 29 Januari 2016 